\title{
Movements of three large coastal predatory fishes in the northeast Atlantic: a preliminary telemetry study
}

\author{
PABLO PITA and JUAN FREIRE
}

\author{
Grupo de Recursos Marinos y Pesquerías. Universidad de A Coruña. Rúa da Fraga, 10. E-15008.
} A Coruña, Spain. E-mail: jfreire@udc.es.

\begin{abstract}
SUMMARY: Labrus bergylta, Dicentrarchus labrax and Conger conger are common predators of northeast Atlantic coastal ecosystems and are studied here for the first time with ultrasonic telemetry in their natural environment. We demonstrate the viability of using this technology with these species and used movement information to obtain preliminary short-term results on site fidelity, diel activity patterns and home range sizes. Two complementary telemetry methods were used: manual and automatic tracking along a stretch of coast characterized by its high wave exposure (A Coruña, NW Spain). C. conger stayed in the area for the longest periods of time (17 days), occasionally leaving their refuges at dusk or during the night to search for food. Their home range was very small $\left(604 \mathrm{~m}^{2}\right)$. L. bergylta were not detected by the automatic receivers but the size of their home range (between 2874 and $5184 \mathrm{~m}^{2}$ ), shows that they are highly sedentary with very limited movements. D. labrax left the area for the longest periods ( 9 days) and were detected during both night and day. Their home range was the largest (up to $26396 \mathrm{~m}^{2}$ ), evidencing complex spatial behaviour on a large scale.
\end{abstract}

Keywords: coastal predatory fish, habitat use, site fidelity, home range, diel activity, tagging, telemetry, VR2, VR100.

RESUMEN: MOVIMIENTOS DE TRES GRANDES PECES DEPREDAdORES COSTEROS DEL NORESTE ATLÁNTICO: Un ESTUDIO PRELIMINAR MEDIANTE TELEMETRíA. - Labrus bergylta, Dicentrarchus labrax y Conger conger son depredadores habituales de los ecosistemas costeros del Noreste Atlántico que en este trabajo se estudian por vez primera mediante telemetría ultrasónica en el medio natural. Se demostró la viabilidad del uso de esta tecnología con estas especies y la información sobre sus movimientos se usó para obtener resultados preliminares a corto plazo acerca de la fidelidad al hábitat, la temporalidad diaria de la actividad y el tamaño del área vital. Se emplearon complementariamente dos métodos de telemetría: seguimiento manual y automático en un tramo de costa caracterizado por su elevado grado de exposición al oleaje (A Coruña, NW Spain). Los C. conger permanecieron en el área durante los períodos más largos (17 días), abandonando periódicamente sus refugios al atardecer o durante las noches para buscar alimento. El tamaño de su área vital fue muy pequeño $\left(604 \mathrm{~m}^{2}\right)$. Los L. bergylta no fueron detectados en los receptores automáticos, pero el tamaño de su área vital (entre 2874 y $5184 \mathrm{~m}^{2}$ ), evidencia un elevado grado de sedentarismo y movimientos muy limitados. Por el contrario, los D. labrax abandonaron el área durante los intervalos más prolongados ( 9 días), detectándose igualmente durante el día o la noche. Su área vital fue la de mayor tamaño (hasta $26396 \mathrm{~m}^{2}$ ), evidenciándose un comportamiento espacial complejo y a gran escala.

Palabras clave: peces depredadores costeros, uso del hábitat, fidelidad al hábitat, área vital, actividad diaria, marcaje, telemetría, VR2, VR100.

\section{INTRODUCTION}

It is very interesting to have accurate knowledge of the habitat use of marine predators because they are indicators of the health of the ecosystem they inhabit (Myers and Worm, 2003; Myers et al., 2007). Traditionally, tag-recapture techniques (Shepherd, 1988) and direct observation (Murphy and Jenkins, 2010) have been used to study movement patterns and habitat use preferences of marine animals, but these methods have limitations (Kearney, 1989, Murphy and Jenkins, 2010). The recent innovations in underwater ultrasonic telemetry allow accurate information on different aspects of fish habitat use to be obtained with very high resolution (Winter, 1996, Golet et al., 2006; Jorgensen et al., 2006). Consequently, in recent years there has 
been an increase in the number of works that use this technology to study the behaviour of different fish species (George, 2007). However, there is still little information about the home range size, habitat selection criteria and activity patterns of the populations of many coastal fish species (Topping et al., 2005), especially in temperate zones (Lowe et al., 2003).

Labrus bergylta (Ascanius 1767), Dicentrarchus labrax (Linnaeus 1758) and Conger conger (Linnaeus 1758) are some of the most common predators of the northeast Atlantic coastal ecosystems (Pita and Freire, unpublished data). Several European fisheries have traditionally exploited these species and currently there is growing commercial interest in them. However, many aspects related to their habitat use are still unknown (Darwall et al., 1992, O'Sullivan et al., 2003, Fritsch et al., 2007).

L. bergylta are protogynous hermaphrodites with slow growth and high longevity (up to 29 years old). They undergo sex inversion at a wide range of sizes (Dipper et al., 1977). They have a maximum body size of $65.9 \mathrm{~cm}$ (TL) and a weight of $4.4 \mathrm{~kg}$ (IGFA, 2001), and are associated with coastal rocky bottoms up to 20 $m$ in depth (Rodríguez and Vázquez, 1994). They are distributed throughout the northeast Atlantic (Quignard and Pras 1986), feeding mainly on crustaceans and molluscs (Dipper et al., 1977).

D. labrax are demersal fish that reach a maximum of $103 \mathrm{~cm}$ (TL; IGFA, 2001) and $12.0 \mathrm{~kg}$ (Fiedler, 1991). They are distributed throughout the northeast Atlantic and Mediterranean (Lloris, 2002) and inhabit waters of all types of coastal environments, feeding on fish, crustaceans and molluscs (Rodríguez and Vázquez, 1994). They are very active predators that migrate seasonally and occasionally enter estuaries and rivers (Frimodt, 1995).

C. conger, distributed in the northeast Atlantic and Mediterranean, are large benthic fish that reach maximum lengths of $300 \mathrm{~cm}$ (TL; Smith, 1990) and weights of $110 \mathrm{~kg}$ (Muus et al., 1999). Juveniles mainly inhabit coastal areas, as they migrate to deeper areas when they become mature (Maigret and Ly, 1986). They normally inhabit depths between 0 and $500 \mathrm{~m}$ (Smith, 1990), but Mytilineou et al., (2005) found them at more than $1000 \mathrm{~m}$ depth. They are nocturnal predators (Göthel, 1992) and feed on fish, crustaceans and cephalopods (Bauchot and Saldanha, 1986). They spawn once in their life, seemingly in the area of the Azores Islands (Mc Cleave and Miller, 1994) and in the middle of the Mediterranean Sea (Cau and Manconi, 1983).

L. bergylta, D. labrax and C. conger have never been studied with telemetry in their natural environment. In this work we explored the potential use of telemetry techniques to investigate the movements of these species in Galician waters (NW Spain). We analyzed the influence of tagging on the behaviour of the fish and quantified the position error in the manual tracking. In addition, preliminary short term information was obtained on site fidelity, diel activity patterns and home range size for some individuals of the three species. Two complementary ultrasonic telemetry methods were used: manual tracking with a portable receiver and automatic tracking through fixed receiver stations installed under the water.

\section{MATERIALS AND METHODS}

\section{Study area}

This study was carried out around the San Pedro Islands in A Coruña, NW Spain ( $\left.43^{\circ} 38^{\prime} \mathrm{N} ; 8^{\circ} 45^{\prime} \mathrm{W}\right)$, an area that is highly exposed to ocean waves (waves $\geq 2 \mathrm{~m}$ during 58\% of annual time, Ministerio de Fomento, 1998-2010). The archipelago is formed by a set of 4 main granite islands and various islets with a surface of approximately 19 ha and maximum altitude above sea level of $12.40 \mathrm{~m}$ (Martínez et al., 2006). The islands are arranged parallel to the continent, forming a channel of calm shallow waters $(<20 \mathrm{~m})$ of approximately 70 ha (Fig. 1).

We selected this area because the three studied fish species occur in it with densities ranging between low (25 C. conger and 338 D. labrax per ha) and abundant (2644 L. bergylta per ha; Pita et al., unpublished data). The three species are valued by the recreational fisheries in Galicia (underwater and angling) and are intensively exploited by commercial fisheries along the entire Galician coast (Xunta de Galicia, 2001-2010), but in the study area only $C$. conger support a large commercial fishing effort (Pita et al., 2008).

\section{Tagging technique}

All of the fish studied in this work were caught in the study area with traps or fishing line and were released in the place where they had been caught. To reduce handling stress, some of the specimens were anesthetized with clove oil (eugenol; $0.10-0.16 \mathrm{~mL} / \mathrm{L}$ during 30-45 $\mathrm{min}$ ) to sedation level 4 (total loss of bal-

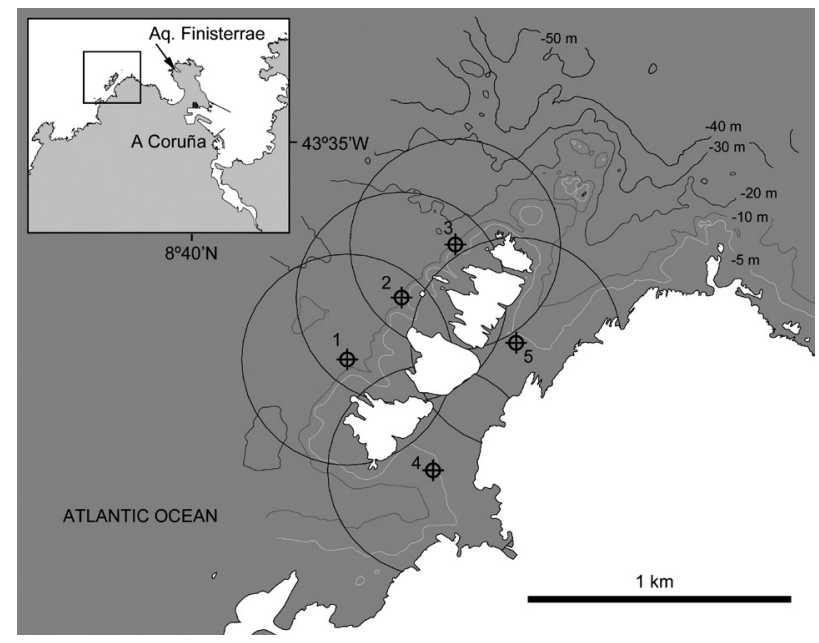

FIG. 1. - Map of the study area, indicating the location and range of the telemetry receivers. 
TABLE 1. - Individuals tagged for the automatic and manual tracking. The catch date, total length (TL) and weight, and the anaesthetic dose administered are indicated.

\begin{tabular}{|c|c|c|c|c|c|}
\hline Specimen & Tag & Captured & $\mathrm{TL}(\mathrm{cm})$ & Weight (g) & Anaesthetic $\left(\mathrm{mL} \cdot \mathrm{L}^{-1}\right)$ \\
\hline L. bergylta & dummy & $23 / 04 / 2008$ & 20 & 800 & $1.00^{\dagger}$ \\
\hline C. conger & - & $23 / 04 / 2008$ & 80 & - & - \\
\hline C. conger $^{\S}$ & dummy & $03 / 04 / 2008$ & 150 & - & 0.06 \\
\hline C. conger \# 1 & coded & $04 / 05 / 2008$ & 150 & - & 0.16 \\
\hline C. conger \# 2 & coded & $14 / 05 / 2008$ & 150 & - & 0.14 \\
\hline C. conger \# 3 & coded & $14 / 05 / 2008$ & 100 & - & 0.10 \\
\hline D. labrax \# 4 & coded & $11 / 05 / 2008$ & 30 & 550 & 0.05 \\
\hline D. labrax \# 5 & coded & $13 / 05 / 2008$ & 43 & 2850 & - \\
\hline D. labrax \# 6 & coded & $13 / 05 / 2008$ & 35 & 1300 & - \\
\hline L. bergylta \# 7 & coded & $15 / 05 / 2008$ & 25 & 800 & - \\
\hline L. bergylta \# 8 & coded & $15 / 05 / 2008$ & 20 & 600 & - \\
\hline L. bergylta \# 9 & coded & $15 / 05 / 2008$ & 20 & 600 & - \\
\hline L. bergylta \# 10 & coded & $15 / 05 / 2008$ & 25 & 900 & 0.03 \\
\hline L. bergylta \# 11 & continuous & $24 / 08 / 2008$ & 20 & 1000 & - \\
\hline C. conger \# 12 & continuous & $01 / 09 / 2008$ & 70 & - & 0.12 \\
\hline L. bergylta \# 13 & continuous & 09/09/2008 & 35 & 2200 & - \\
\hline D. labrax \# 14 & continuous & $28 / 09 / 2008$ & 20 & 700 & - \\
\hline D. labrax \# 15 & continuous & 02/10/2009 & 20 & 1000 & - \\
\hline
\end{tabular}

$\dagger$ Lethal dose; C. conger ${ }^{\S}$ is the same fish as C. conger \#1 (captured date of C. conger \#1 corresponds to released date).

ance). We glued a T-tag (Floy Tag Inc.) on each end of the telemetry transmitters with epoxy resin (supplementary material, Appendix 1). The transmitters were externally attached to the fish with a pistol, which makes the process quick ( $<2 \mathrm{~min})$. The tags were attached to the back of L. bergylta and D. labrax, at the level of the first radius of the dorsal fin, and below the scapular fins in $C$. conger. An additional nylon string was glued to the centre of the tags for L. bergylta and D. labrax and was sutured subcutaneously to provide a third anchoring point. All of the materials used were first submerged in an antiseptic solution and an antibiotic ointment was applied to the insertion points. The tags did not exceed $2.0 \%$ of the fish's weight and the anesthetized fish were kept in a mesh cage at the place of capture until they had recovered fully (3 to $6 \mathrm{~min}$ ) before being released (Table 1).

\section{Influence of tagging on fish behaviour}

We arranged various samples to catch fish of the species studied to assess the influence of tagging on their behaviour in the installations of the Aquarium Finisterrae (A Coruña; Fig. 1). We were able to obtain only 2 specimens of $C$. conger and 1 of L. bergylta (Table 1), mostly due to hard weather, poor sea conditions and derived fishing problems. The L. bergylta was caught in the study area and transported (less than an hour drive) in a container with mechanical aeration to a 3000-L tank. The tank was replenished with $375 \mathrm{~L} \mathrm{~h}^{-1}$ of water taken from the study area. C. conger were caught with the same protocol and placed in an 800-L tank with a closed circuit and mechanical filtration. The temperature, dissolved oxygen, $\mathrm{pH}$, salinity and nitrogen compounds of the tanks were measured daily and did not differ significantly from those of the study area.

Dummy tags made of resin were attached to the $L$. bergylta and one of the $C$. conger following the protocol already explained. The dummy tags had the same weight and size as the real ones and had an anchorage point at each end. The tagged $C$. conger had air inside its body cavity from when it was caught, so on the seventh day of captivity PVC tubes were placed in the tanks so that the fish could stay on the bottom. The behaviour of the fish was observed every 10 minutes during the first 6 hours and then twice a day during the rest of the captivity period. Specifically, in each specimen the following behaviours were observed:

1. Floating. The fish was considered to be floating if part of its body was at the surface of the water and not floating when it was on the bottom.

2. Equilibrium. If the deviation of the longitudinal plane of the fish with respect to the vertical was estimated to be larger than $10^{\circ}$, the fish was considered unbalanced and if the angle was not larger than $10^{\circ}$ it was considered to be balanced.

3. Activity. If the fish moved it was considered active and if it was immobile, inactive.

4. Feeding. Whether or not the fish was eating the food offered.

The behaviour observations were introduced into databases for each species in which each case corresponded to one observation $(\mathrm{N}=55$ for L. bergylta and $\mathrm{N}=146$ for $C$. conger; Fig. 2). Multiple regression models were used to analyze the influence of the time since tagging (as a quantitative predictor variable) on the behaviour of the fishes (response variables). Additionally, the behaviour of the tagged and untagged individuals was compared in the case of the models for C. conger (as a qualitative predictor variable with two levels, tagged and untagged). Different logistic generalized additive models were fitted (GAM; Hastie and Tibshirani, 1990) with a binomial error structure and logit link with statistical package $\mathrm{R}$, version 2.9.2 ( $\mathrm{R}$ Development Core Team, 2008). We used penalized thin-plate regression splines (Wood, 2003) to fit the models and the flexibility of the $m g c v$ packet (Wood, 2000) for the smoothing functions. To select the most 


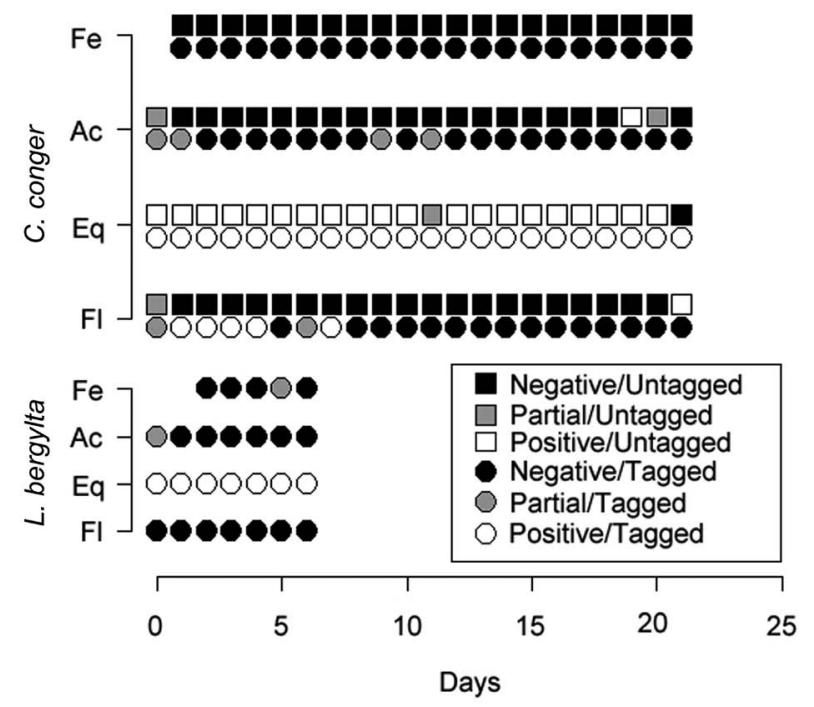

FIG. 2. - Behaviour of $C$. conger and L. bergylta in captivity. Feeding (Fe), activity (Ac), equilibrium (Eq) and flotation (Fl) are shown. White $=$ positive along all day; grey $=$ different along the day; black $=$ negative during all day. The shape indicates whether the fish is tagged with a dummy tag or not.

appropriate model in each case, Akaike's criterion (Akaike, 1973) was used when possible and when it was not the percentage of explained deviance was used. The area under the ROC curve (AUC) was calculated to validate the models (Harrell, 2001), the gam.check tool was used to control the residuals and the predict tool was used to obtain inferences from the definitive model (this fit, selection and inference structure was used for the rest of the GAMs employed in this work, Table 2; the model outputs can be seen in the supplementary material, Appendix 2).

\section{Site fidelity and diel activity pattern}

Between 10 and 15 April 2008, 5 VR2 acoustic receivers (VEMCO Ltd.) were installed in the study area. These receivers stored the date and time of the signals transmitted by the telemetry tags within their detection area. A range test was carried out previously in the study area and it was determined that these receivers have a maximum reception distance of $400 \mathrm{~m}$; therefore, to maximize the spatial cover, 2 receiver stations were situated in the non-exposed area and 3 in the exposed area (Fig. 1). The receivers situated at stations 1 and 3 were lost due to waves, but station 1 was recovered in March 2010. The rest of the receivers were taken in on 19 April 2009.

Between 4 and 15 May 2008, 4 specimens of $L$. bergylta, 3 of D. labrax and 3 C. conger were tagged and released in the study area (Table 1). We used 69 $\mathrm{kHz} \mathrm{V} 13-1 \mathrm{H}$ coded pingers (VEMCO Ltd.) of 36x13 $\mathrm{mm}$, which transmitted signals that allowed them to be recognized individually. The estimated battery life was approximately 300 days (silence intervals of 50 to $130 \mathrm{~s})$.
The data stored in the receivers was downloaded with the VUE 1.4.2 software (VEMCO Ltd.). The information was organized and coded in databases, indicating whether the fish was detected during the dawn, day, dusk or night of each of the 300 days following their release. Dawn was defined as the 2 hours before sunrise, and dusk as the 2 hours before sunset. This information was used to study the site fidelity and diel activity pattern of each species with GAMs (Table 2). Site fidelity was measured as the probability of detection at one or more stations in relation to the time elapsed since the fish was released. The diel activity pattern was determined as the probability of detection according to the time of day.

\section{Mean speed, distance covered daily and home range size}

Manual tracking was carried out in August and September 2008 and in October 2009. Two L. bergylta, 2 D. labrax and 1 C. conger (Table 1) were tagged with a V13-1H continuous pinger of 36x13 mm and 60 to 84 $\mathrm{kHz}$ (VEMCO Ltd.). To locate the animals we used a directional hydrophone (VH110) connected to a portable VR100 receiver (VEMCO Ltd.) that receives and stores the signals transmitted by the tags ( 1 per $s)$, the date and time of the signal, the signal strength $(\mathrm{dB})$, the gain $(\mathrm{dB})$ and the geographical position of the receiver determined by means of an internal GPS. Each fish was tracked individually and continuously on a boat during the $48 \mathrm{~h}$ following its release, and when sea conditions allowed the fish continued to be tracked on the following days (Table 3 ).

The detections were used to calculate the distance in $\mathrm{m}$ between successive positions $\left(D_{A \rightarrow B}\right)$ :

$$
D_{A \rightarrow B}=\sqrt{\left(\left(\text { Lon }_{A}-\text { Lon }_{B}\right)^{2}+\left(\text { Lat }_{A}-\text { Lat }_{B}\right)^{2}\right)}
$$

where $\operatorname{Lon}_{A}$ and $L a t_{A}$ are the geographic coordinates (UTM) of the first position, and $\operatorname{Lon}_{B}$ and $L a t_{B}$ are the final geographic coordinates.

Similarly, in function of the time between detections, the mean speed $\left(\mathrm{m} \mathrm{s}^{-1}\right)$ was obtained between successive positions. Then, in function of the total distance travelled and the total tracking time, the distance travelled in each 24 -h period (in m day ${ }^{-1}$ ) was estimated for each fish.

Finally, the detection databases were introduced into a GIS and analyzed with the Animal Movement Analyst Extension 1.1 to Arcview (Hooge and Eichenlaub, 1997). A layer with the bathymetric surface generated by single beam data, obtained in an acoustical survey with 5-10 m grid resolution (Sánchez-Carnero and Aceña, pers. comm.), was also introduced into the GIS. The fixed kernel home range utilization distribution was calculated by ad hoc calculation of a smoothing parameter; we consider the $50 \%$ contour as the core activity area $\left(\mathrm{m}^{2}\right)$ and the $95 \%$ contour $\left(\mathrm{m}^{2}\right)$ as the home range (Hooge et al., 1997). Only the positions 

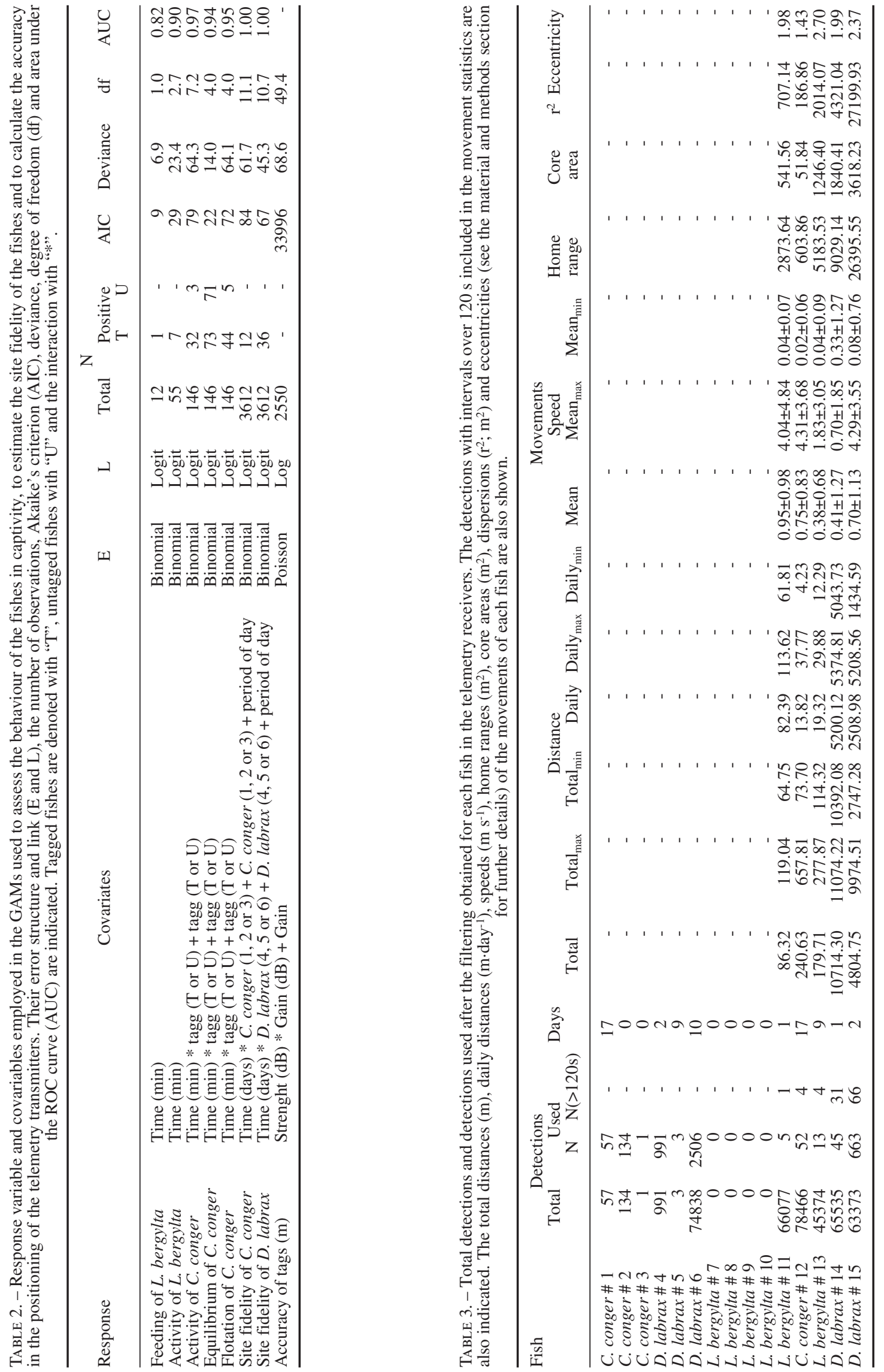


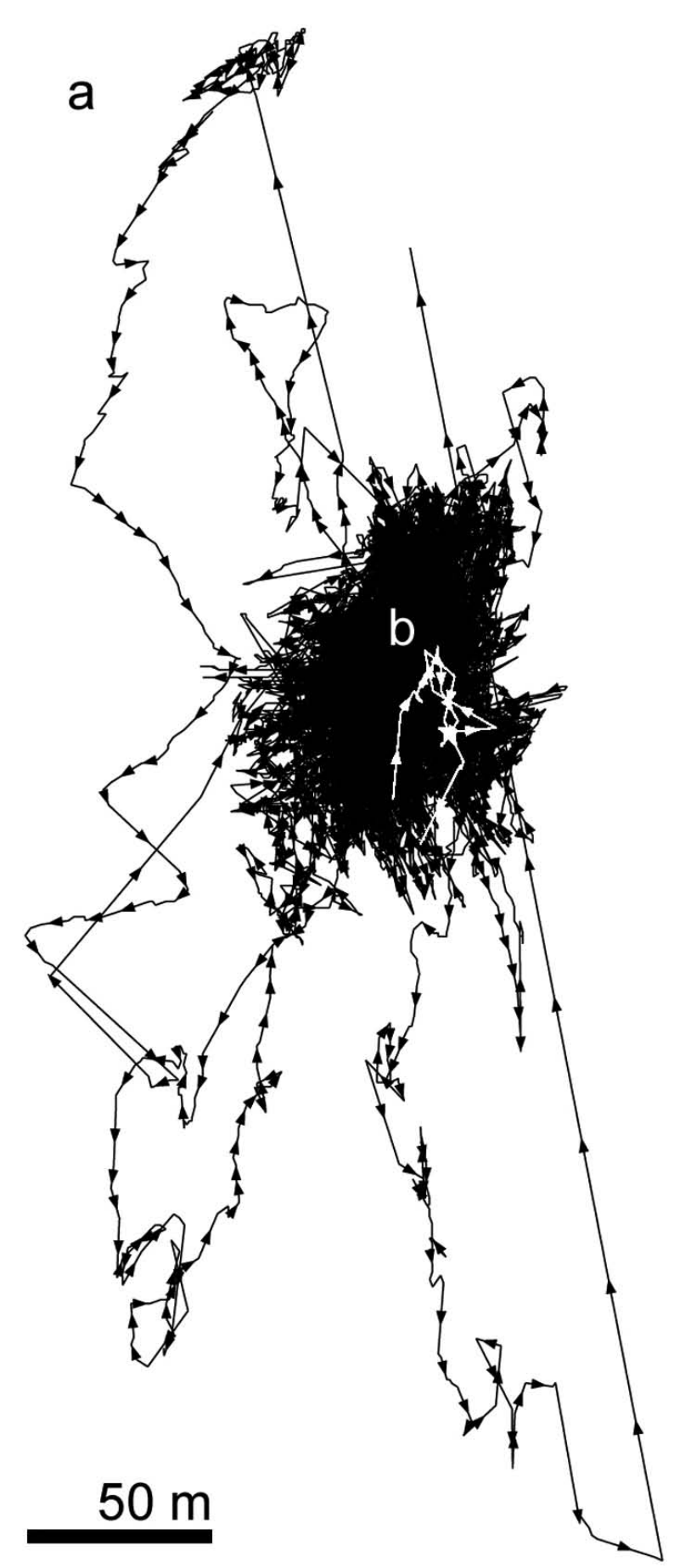

FIG. 3. - As an example, the route followed by C. conger number 12 is shown without filtering (a) and after being filtered (b).

obtained within the study area were used, excluding the movements of the fish in leaving the area permanently.

The program also measured the dispersion of the movements $\left(r^{2}\right)$ with the mean-squared distance from the centre of activity and the eccentricity by the ratio between the minor and major axes of the range length (close to 1 indicates a circular range shape, and greater than 1 increasingly elongate).
Accuracy of the movement estimates obtained with manual tracking

Determining the accuracy of telemetry techniques is interesting for when the results are analyzed, but these types of result are not often found in scientific works. Golet et al. (2006) filtered the original positions to improve the positions obtained with complex and already very precise telemetry technology (RAPT system). However, Sackett et al. (2007), with manual telemetry systems similar to those employed here, selected reception strengths of $120 \mathrm{~dB}$, with gains $\leq 12 \mathrm{~dB}$ to obtain resolutions at a scale of metres.

In this work we have increased the spatial resolution of our results, selecting the positions associated with higher reception strengths (threshold of 100-105 $\mathrm{dB})$ and lower gains ( $<6 \mathrm{~dB}$; Fig. 3). In addition, in September 2008 a test was carried out to check the accuracy of the V13-1H transmitters and calculate the error in the position of each detection $(D E)$.

One of the transmitters was located in an area with a depth of $17 \mathrm{~m}$, suspended $1.5 \mathrm{~m}$ above the bottom. The hydrophone was placed in the water over the transmitter to receive the signal for $1 \mathrm{~min}$ at 11 separate positions every $10 \mathrm{~m}$ (between 0 and $100 \mathrm{~m}$ ). This procedure was repeated for different gains $(0,6,12,18,24$ and $30 \mathrm{~dB})$. The receiver was downloaded with the VR100 Host Software 2.2 (VEMCO Ltd.) and the information was organized into databases that related the strength of each detection with the distance from the transmitter for each gain. GAMs (Table 2) were used to predict the distance to the transmitter in relation to the gain and the reception strength (Fig. 4). A maximum $D E$ of \pm 4.09 $\mathrm{m}$ was estimated by positioning a signal received with a strength $\geq 100 \mathrm{~dB}$ and a gain $\leq 6 \mathrm{~dB}$ (supplementary material, Appendix 3).

Taking into account the $D E$ associated with each position $( \pm 4.09 \mathrm{~m})$, the maximum $\left(D_{\max }\right)$ and minimum $\left(D_{\min }\right)$ distances between positions (in m) were estimated to obtain a confidence interval for each route:

$$
D_{\max }=D_{A \rightarrow B}+2|D E| \text { and } D_{\min }=D_{A \rightarrow B}-2|D E|
$$

\section{RESULTS}

\section{Influence of tagging on fish behaviour}

C. conger did not accept the food provided in captivity, so we ended the experiment after 21 days. No significant differences between tagged and untagged animals in terms of activity were observed $(\mathrm{p}=0.543)$, although this behaviour varied over time $(P \leq 0.008)$. The two $C$. conger were active at the beginning of the experiment and remained relatively inactive from the second day. Between days 9 and 11 the tagged $C$. conger showed periods of activity and then remained inactive. However, the untagged $C$. conger increased its activity towards the end of the period. No differ- 

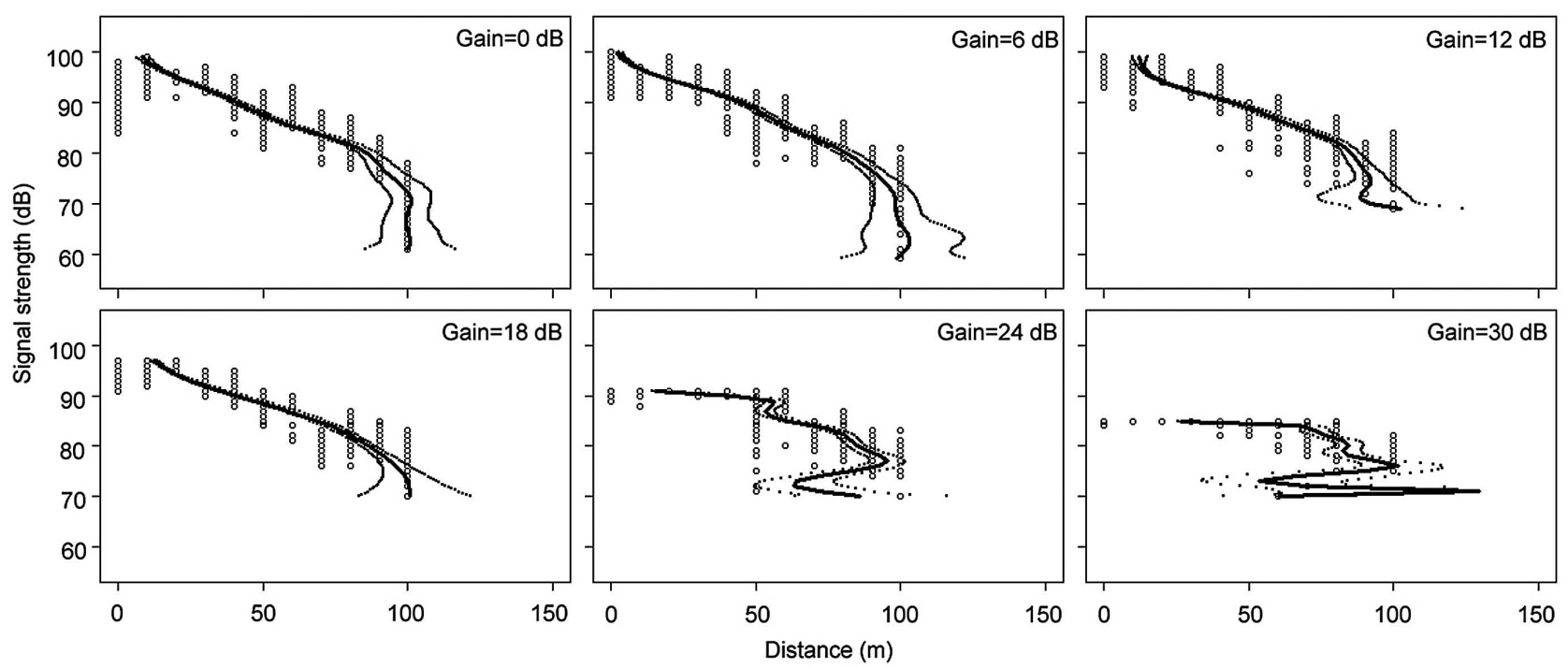

FIG. 4. - Results of the accuracy test of the movement estimates obtained with manual tracking carried out with a VR 100 receiver (VEMCO Ltd.). The points indicate the reception strengths $(\mathrm{dB})$ obtained in relation to the distance to the transmitter (in $\mathrm{m}$ ) and the gain (dB). The prediction (unbroken line) and the SE (line of points) obtained with GAMs are represented.

ences between the equilibrium of $C$. conger $(\mathrm{p}=1.0)$ were observed, but the untagged animal showed a significant unbalanced tendency towards the end of the experiment $(P<0.001)$. Differences were observed regarding the flotation of $C$. conger $(P<0.001)$ : the untagged $C$. conger stayed on the bottom for almost the entire experiment $(P>0.900)$, while the tagged animal floated during the first 7 days $(P<0.001 ;$ Fig. 2 and supplementary material, Appendix 2).

The tag of the L. bergylta fell off on day 6 of captivity. The fish died due to excessive anaesthetic during retagging $\left(1.0 \mathrm{~mL} \mathrm{~L}^{-1}\right.$ for $\left.1 \mathrm{~min}\right)$. During the entire experiment it remained balanced and at the bottom of the tank. Its feeding activity and behaviour during captivity did not vary significantly over time $(P \geq 0.900)$, although on the first day it was more active and on the fifth day it accepted the supplied food (Fig. 2 and supplementary material, Appendix 2).

\section{Site fidelity and diel activity pattern}

A total of 192 signals were detected coming from $C$. conger and 3500 from D. labrax, but no signals were detected from L. bergylta. In reality the number of detections of $D$. labrax was higher, because number 6 was detected continuously at station 4 from the fourth day from its release until the end of the experiment and sometimes at stations 1 and 5 until day 10 . We interpreted this as indicating that the fish had died or lost its tag after day 10, so detections after this day were not included in the analysis (Table 3 ).

The detection probability for $C$. conger decreased as the time from release increased $(P \leq 0.006)$. Although no differences were found between the specimens $(P \geq 0.058), C$. conger numbers 2 and 3 were only detected on the day they were released, while $C$. conger number 1 was detected intermittently between days 4 and 17. Differences were found in the period of day in relation to the probability of detecting $C$. conger, as they were more likely to be detected at dusk or at night $(P \leq 0.003)$. All the detections of $C$. conger were obtained on receivers situated in the non-exposed area (Fig. 5; supplementary material, Appendix 2 and 4).

The time elapsed since release also decreased the detection probability of $D$. labrax $(P \leq 0.001)$, but in this case the differences between specimens were significant $(P<0.001)$. D. labrax number 4 was detected from its release until it left the area on the second day. However, D. labrax numbers 5 and 6 left the area on the day they were released; D. labrax number 6 returned in 2 days (and then lost its tag or died) and $D$. labrax number 5 returned during the first hours of day 9 , and was detected at the two stations in the exposed area. The detection probability was higher during the day and night than at dawn or dusk $(P<0.001$; Fig. 5 and Supplementary material Appendix 2 and 4).

\section{Mean speed, distance covered daily and home range size}

A total of 111451 position signals came from L. bergylta, 78466 from $C$. conger number 12 and 128908 from $D$. labrax, although the later filtering greatly reduced the number of positions used. In addition, D. labrax number 15 stopped moving $46 \mathrm{~h}$ after tracking began. This was interpreted as indicating that the tag had been lost or the fish had died, so detections made after this time were not included in the analysis (Table 3 ).

The fish moved in the study area with mean speeds that ranged between $0.38 \pm 0.68$ (SE) and $0.95 \pm 0.98$ $\mathrm{m} \mathrm{s}^{-1}$. The mean speeds of $L$. bergylta were the most extreme, L. bergylta number 11 being the quickest $\left(0.95 \pm 0.98 \mathrm{~m} \mathrm{~s}^{-1}\right)$ and number 13 the slowest $(0.38 \pm 0.68$ 


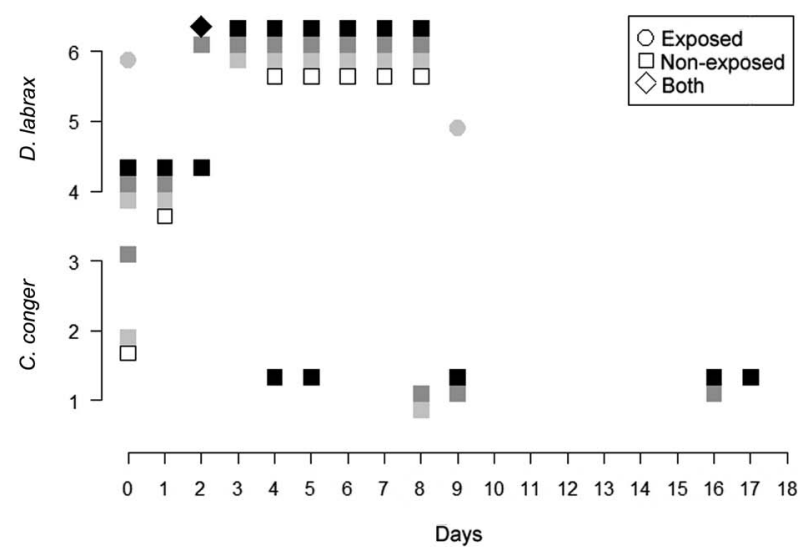

FIG. 5. - Detections in the automatic receivers by fish and time of day $($ white $=$ dawn, light grey $=$ day, dark grey $=$ dusk, black = night). The circles indicate detections in receivers situated in the non-exposed area, the squares detections in receivers situated in the exposed area and the diamonds in both.

$\left.\mathrm{m} \mathrm{s}^{-1}\right)$. D. labrax had intermediate speeds (between $0.41 \pm 1.27$ and $0.70 \pm 1.13 \mathrm{~m} \mathrm{~s}^{-1}$ ), while the movements of $C$. conger were moderately fast $\left(0.75 \pm 0.83 \mathrm{~m} \mathrm{~s}^{-1}\right)$. However, the distances travelled by the $C$. conger and L. bergylta (between 13.82 and $82.39 \mathrm{~m} \mathrm{day}^{-1}$ ) were much more restricted than those travelled by D. labrax (between 2508.98 and $5200.12 \mathrm{~m} \mathrm{day}^{-1}$ ). Consequently, the home ranges of L. bergylta and the $C$. conger (between 603.86 and $5183.53 \mathrm{~m}^{2}$ ) were smaller than those of D. labrax (between 9029.14 and $26395.55 \mathrm{~m}^{2}$; Fig. 6 and Table 3).
D. labrax number 14 left the area of the San Pedro Islands $48 \mathrm{~h}$ after tracking began, travelling $8629 \mathrm{~m}$ until its signal was lost (Fig. 6). During this time a cruising speed of $2.66 \pm 3.14 \mathrm{~m} \mathrm{~s}^{-1}$ was estimated for this fish (between $2.65 \pm 3.13$ and $2.67 \pm 3.14 \mathrm{~m} \mathrm{~s}^{-1}$ taking into account the $D E$ ) and a maximum velocity of $8.25 \mathrm{~m}$ $\mathrm{s}^{-1}\left(8.22-8.28 \mathrm{~m} \mathrm{~s}^{-1}\right)$.

\section{DISCUSSION}

In this paper we demonstrate the viability of using underwater ultrasonic telemetry with L. bergylta, $D$. labrax and $C$. conger in their natural environment. The telemetry techniques employed here have great potential for studies on the movements and habitat use of the three species. Furthermore, we have modified widely used methodologies, such as the external tagging technique, and introduced innovations, such as measuring the $D E$, that may be of interest for future work on fishes and many other aquatic animals. However, the results of the movements of the fishes showed here must be considered as preliminary. The objectives for future studies of these species should include increasing the number of fish tagged and improving the long-term reliability of the tagging. Thus, a greater number of observations can be obtained, especially in the long term. Pine et al. (2003) recommend pilot studies to test the retention of marks and testing the feasibility of surgically implanted brands would be of great interest.

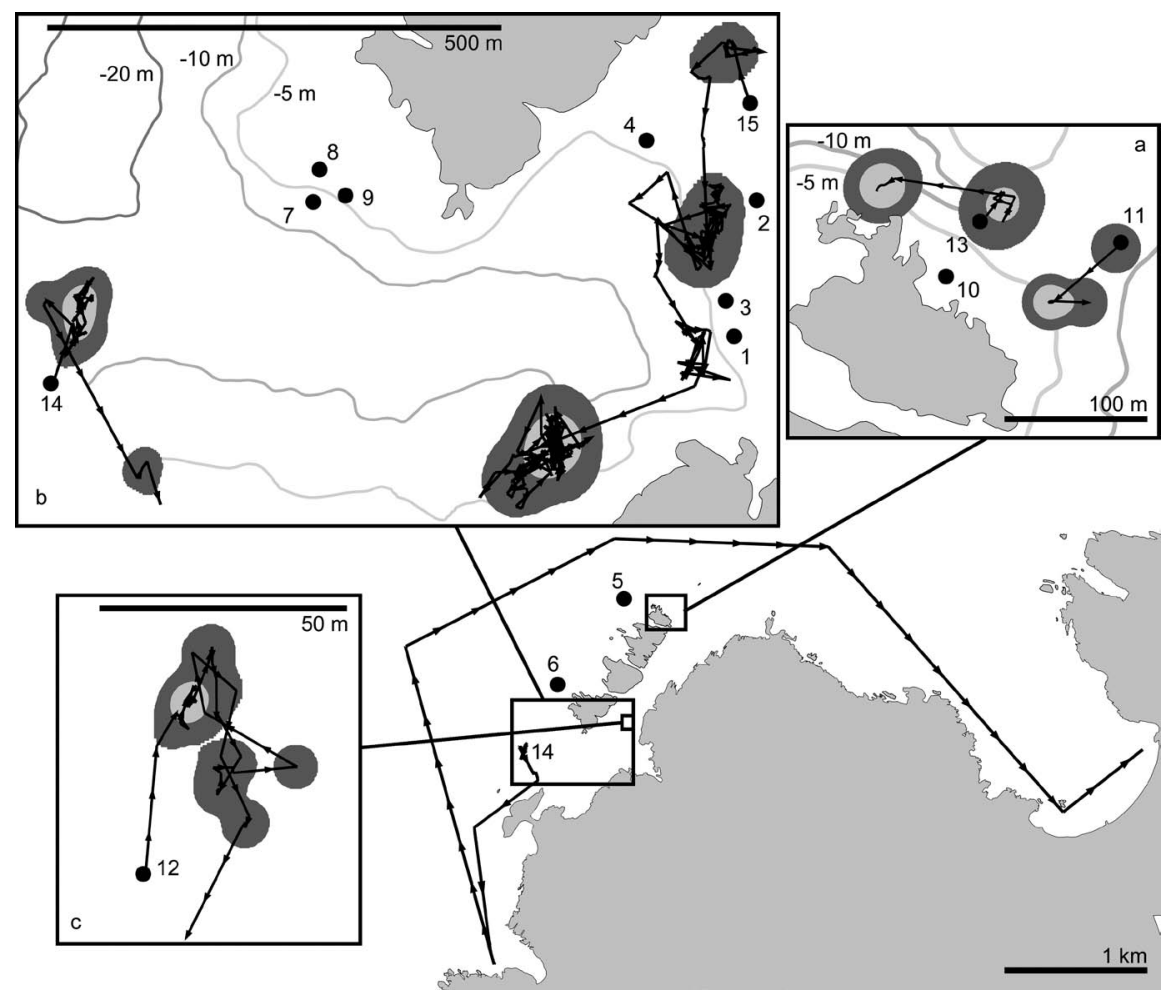

FIG. 6. - Movements, home ranges (dark grey) and core areas (light grey) obtained for fish followed with manual tracking. The dots indicate the site of catch and release. Fishes numbers $1-3$ and 12 are $C$. conger, numbers 4-6, 14 and 15 are D. labrax and numbers 7-10 and 13 are $L$. bergylta. The movements of D. labrax number 14 near the end of its 48-h tracking period are also shown. 
In telemetry studies, before carrying out field experiments it is important to determine the tag retention and mortality rates and to analyze how the tags influence the behaviour of the animals (Fabrizio and Pessutti, 2007). The use of surgery is often a good option in long-term telemetry studies, as internal tags can remain in the fish for years without giving problems (Jepsen et al., 2002). In addition, in some studies that employed external tags, a large number of tags were found to fall off (Sackett et al., 2007). However, the surgical implantation technique is complicated and has been associated with a high risk of mortality, infection and tag loss, all of which have been used as arguments in favour of external implantation (Jepsen et al., 2002). $\varnothing$ kland et al. (2001) compared the two methods and obtained better results with external tags. Moreover, anaesthetic is often not needed when external tags are attached to the fish, so they have even more advantages in the short term (Jepsen et al., 2002).

Both types of implantation have important advantages and disadvantages. In our case, we decided to include a third anchorage point on the tags for L. bergylta and $D$. labrax after finding that the $L$. bergylta tagged in captivity lost its dummy tag. Even so, there was still a certain degree of uncertainty concerning tag retention or the health of some of the fish (such as D. labrax numbers 6 and 15). Therefore, the low number of detections in the long term (after day 17 after release), and even the complete absence of detections in the case of $L$. bergylta, could be related to failures in tagging. However, it is necessary to keep in mind that the limited movement of L. bergylta (confirmed through manual tracking), the complicated bathymetry of the habitat and also their benthic lifestyle would make detecting them difficult, especially with the receivers situated in the exposed area. Moreover, receivers 2 and 3 were lost due to waves (some more than $8 \mathrm{~m}$ high), although their moorings consisted of pieces of $50 \mathrm{~kg}$ concrete deployed at $-15 \mathrm{~m}$ (Fig. 1).

The important advantages of the external tagging technique finally resolved the question of which implantation method to use: it is simple to use even without previous training, it is very quick ( $<2 \mathrm{~min})$ and it does not always require anaesthetic. Consequently, the suffering of the fish is minimized, favouring quick recovery and an earlier return to normal activity, which is vitally important in behaviour studies. In addition, the anaesthetic used (eugenol) is efficient, the fish recover quickly and with high survival rates and it is not toxic for humans or the environment (Jepsen et al., 2002, Pastor et al., 2009).

Moreover, we found that the tagging process did not affect the behaviour of the fish, although we were finally able to study fewer animals than we expected. In captivity, it was found that the behaviour of C. conger (tagged and control) was not different. The difference in the floating behaviour of the tagged $C$. conger began when it was caught and was solved by placing a refuge on the bottom of the tank. Furthermore, the only specimen to show signs of weakness (unbalanced) was the untagged animal, when we decided to end the experiment and release the animals. The behaviour of the tagged L. bergylta was also normal (balanced and at the bottom of the tank) during the entire experiment, and it even accepted non-living food on the fifth day (Fig. 2).

Løkkeborg et al. (2002) discussed the effect of the position-fixing interval on calculating speeds between successive positions, and found that intervals of more than $120 \mathrm{~s}$ underestimate the speed in $60 \%$ of cases, although intervals of more than $136 \mathrm{~s}$ do not significantly increase this percentage. Lagardère et al. (1990) established that positioning each $15 \mathrm{~s}$ gives good results for estimating the speed of D. labrax. Due to the method used in this study for improving the spatial resolution, the interval between successive positions was not fixed, and varied between $1 \mathrm{~s}$ and $416 \mathrm{~h}$ after the filtering. Consequently, some of the distances and speeds may have been underestimated, although they were mainly obtained with intervals greater than $120 \mathrm{~s}$ (Table 3 ).

A low number of observation days (Topping et al., 2005), fewer than 30-50 localizations (Seaman and Powell, 1996, Seaman et al., 1999) and spatial autocorrelation between observations (Swihart and Slade, 1985) tend to lead to the home range size being underestimated. The filtering carried out to increase the spatial resolution at the same time decreased the temporal resolution of the tracking (between $0.01 \%$ and $1.05 \%$ of the original positions were used, Table 3 and Fig. 3). In our case, the home range sizes were obtained from experiences with a mean of $6 \pm 7$ days and $156 \pm 284$ localizations (Table 3 ). While the number of days and localizations might be low (mostly for $D$. labrax, tracked for a maximum of 2 days), resulting in smaller than expected home ranges even in the short time, we can suppose that the positions derived from the filters, with random intervals between positions, will have kept the autocorrelation in our observations under control.

C. conger, D. labrax and L. bergylta studied here used the habitat in very different ways. $C$. conger showed the highest site fidelity, staying in the area continuously over the longest periods of time (up to 17 days). They used rock refuges to rest, and their long-term detection pattern alternated between long absences (inside the refuge) and periodic appearances (outside the refuge). In addition, they seemed to use the same refuge, given that the short-term movements of C. conger number 12 were not eccentric (eccentricity of 1.43) and the core area of its home range was small (8.58\%; Table 3). The most active periods were dusk and night, and they probably left their refuges to look for food. The excursions lasted between 1 and $7 \mathrm{~h}$ and took place at intervals of between 1 and 7 days (Fig. 5; supplementary material, Appendix 4).

D. labrax left the area for the longest intervals (up to 9 days). There were no differences between night and day in terms of activity, which could be explained by their particular social behaviour; solitary D. labrax 
are nocturnal, while in a group they are more active during the day (Anras et al., 1997, Oca et al., 2005). The route travelled by D. labrax number 14 near the end of the manual tracking period (Fig. 6) and the return of $D$. labrax numbers 5 and 6 to the study area (Fig. 5; supplementary material, Appendix 4), show that this species can cover large distances daily (mean distance of $3855 \pm 1,903 \mathrm{~m} \mathrm{~d}^{-1}$; Table 3 ). The spatial behaviour of the D. labrax studied here is therefore complex and operates at large spatial scales. This is consistent with other studies on this species, which found that D. labrax swim long distances (thousands of kilometres) associated with juvenile recruitment and reproductive and feeding migrations (Pickett et al., 2004, Fritsch et al., 2007).

The limited movements of the studied L. bergylta (Fig. 6 and Table 3) and the absence of detections by the automatic receivers suggest a highly sedentary behaviour, although more studies are needed to confirm it. Other wrasses associated with rocky bottoms show high site fidelities (Topping et al., 2006) and well defined and relatively small home ranges (Topping et al., 2005). García-Castrillo (2000), defined this particular species as being strongly territorial; according to Darwall et al. (1992), they do not carry out migrations. The mean home range size obtained $\left(4029 \pm 1633 \mathrm{~m}^{2}\right.$; Table 3 ) is comparable to that calculated by Topping et al. (2005) for other wrasse from temperate waters and similar habitats $\left(15134 \pm 26007 \mathrm{~m}^{2}\right)$.

The present work represents the first study that uses telemetry for $C$. conger and L. bergylta and the first for D. labrax in its natural environment. There are previous experiences with $D$. labrax in captivity and in mesocosm enclosures (Anras et al., 1997, Lagardère et al., 1990, Webber et al., 2001, Oca et al., 2005) but the results would have little to do with those obtained in the natural environment (Hedger et al., 2010). All new information on unknown aspects of the spatial dynamics of fish populations, especially for predators, is of great interest. Therefore, the information on short-term movements provided here is very useful for future work on the ecology of these species, but should be used with caution (given their preliminary nature) in the management of their fisheries.

\section{ACKNOWLEDGEMENTS}

This research was funded by the Autonomous Government of Galicia (Plan Galego de Investigación, Desesnvolvemento e Innovación Tecnolóxica), PECOS project (PGIDIT05RMA10301PR) and cofunded by the Spanish Ministry of Education and Science and by the European Regional Development Fund (ERDF), CONNECT project (CTM2006-09043/MAR). It would also not have been possible without the volunteers who helped so bravely in the hard conditions of work in the field. We also appreciate the help of the Aquarium Finisterrae of A Coruña.

\section{REFERENCES}

Akaike, H. - 1973. Information theory and an extension of the maximum likelihood principle. In: B.N. Petrov and F. Csaki, (eds.), Second International Symposium of Information Theory, pp. 267-281. Akademiai Kiado, Budapest.

Anras, M.L.B., J.P. Lagardére and J.Y. Lafaye. - 1997. Diel activity rhythm of seabass tracked in a natural environment: group effects on swimming patterns and amplitudes. Can. J. Fish. Aquat. Sci., 54: 162-168.

Bauchot, M.L. and L. Saldanha. - 1986. Congridae. In: P.J.P. Whitehead, M.L. Bauchot, J.C. Hureau, J. Nielsen and E. Tortonese (eds.), Fishes of the Northeastern Atlantic and the Mediterranean, pp. 567-574. UNESCO, Paris.

Cau, A. and P. Manconi. - 1983. Sex-ratio and spatial displacement in Conger conger (L.). Rapp. P.-V. Reun. CIESM, 28: 93-96.

Darwall, W.R.T., M.J. Costello, R. Donnelly and S. Lysaght. 1992. Implications of life-history strategies for a new wrasse fishery. J. Fish Biol., 41: 111-123.

Dipper, F.A., C.R. Bridges and A. Menz. - 1977. Age, growth and feeding in the ballan wrasse Labrus bergylta Ascanius 1767. J. Fish Biol., 11: 105-120.

Fabrizio, M.C. and J.P. Pessutti. - 2007. Long-term effects and recovery from surgical implantation of dummy transmitters in two marine fishes. J. Exp. Mar. Biol. Ecol., 351: 243-254.

Fiedler, K. - 1991. Fische. In: D. Starck (ed.), Lehrbuch der speziellen Zoologie, Band II: Wirbeltiere, Teil 2: pp. 1-498. Gustav Fischer Verlag, Jena.

Frimodt, C. - 1995. Illustrated multilingual guide to the world's commercial warmwater fish. Fishing News Books, Oxford.

Fritsch, M., Y. Morizur, E. Lambert, F. Bonhomme and B. Guinand. -2007 . Assessment of sea bass (Dicentrarchus labrax, L.) stock delimitation in the Bay of Biscay and the English Channel based on mark-recapture and genetic data. Fish. Res., 83: 123-132.

García-Castrillo, G. - 2000. Peces de la bahía de Santander y su entorno. Fundación Marcelino Botín, Santander.

George, G.J. - 2007. Acoustic tagging of black drum on Louisiana oyster reefs: movements, site fidelity, and habitat use. $\mathrm{MsC}$ thesis, Louisiana Stat. Univ.

Golet, W.J., D.A. Scopel, A.B. Cooper and W.H. Watson. - 2006. Daily patterns of locomotion expressed by American lobsters (Homarus americanus) in their natural habitat. J. Crustacean Biol., 22: 610-620.

Harrell, F.E. - 2001. Regression modeling strategies: with applications to linear models, logistic regression, and survival analysis. Springer Verlag, New York.

Hastie, T. and R.J. Tibshirani. - 1990. Generalized Additive Models. Chapman and Hall, London.

Hedger, R.D., T.F. Næsje, P.D. Cowley, E.B. Thorstad, C. Attwood, F. Økland, C.G. Wilke and S. Kerwath. -2010 . Residency and migratory behaviour by adult Pomatomus saltatrix in a South African coastal embayment. Estuar. Coast. Shelf Sci., 89: 12-20.

Hooge, P.N. and B. Eichenlaub. - 1997. Animal movement extension to arcview. Alaska Biological Science Centre, U.S. Geological Survey, Anchorage.

Hooge, P.N., B. Eichenlaub, and E.K. Solomon. - 1997. Using GIS to analyze animal movements in the marine environment. Alaska Biological Science Centre, U.S. Geological Survey, Anchorage.

IGFA. - 2001 Database of IGFA angling records until 2001. IGFA, Fort Lauderdale, USA. URL http://www.igfa.org.

Jorgensen, S.J., D.M. Kaplan, A.P. Klimley, S.G. Morgan, M.R. O'Farrell and L.W. Botsford. - 2006. Limited movement in blue rockfish Sebastes mystinus: internal structure of home range. Mar. Ecol. Prog. Ser., 327: 157-170.

Jepsen, N., A. Koed, E.B. Thorstad and E. Baras. - 2002. Surgical implantation of telemetry transmitters in fish: how much have we learned? Hydrobiologia, 483: 239-248.

Kearney, R.E. - 1989. Tagging-solution or problem. In: D.A. Handcock (ed.), Australian Society for Fish Biology tagging workshop, pp. 208. Proceedings no. 5, Aust. Govt. Publ. Serv., Canberra.

Lagardère, J.P., J.J. Ducamp, L. Favre, J.M. Dupin and M. Sperandio. - 1990. A method for the quantitative evaluation of fish movements in salt ponds by acoustic telemetry. J. Exp. Mar. Biol. Ecol., 141: 221-236. 
Lloris, D. - 2002. A world overview of species of interest to fisheries. Chapter: Dicentrarchus labrax. FIGIS Species Fact Sheets. Species Identification and Data Programme-SIDP. FAOFIGIS, 3.

Løkkeborg, S., A. Ferno and T. Jørgensen. - 2002. Effect of position-fixing interval on estimated swimming speed and movement pattern of fish tracked with a stationary positioning system. Hydrobiologia, 483: 259-264.

Lowe, C.G., D.T. Topping, D.P. Cartamil and Y.P. Papastamatiou. - 2003. Movement patterns, home range, and habitat utilization of adult kelp bass Paralabrax clathratus in a temperate no-take marine reserve. Mar. Ecol. Prog. Ser., 256: 205-216.

Maigret, J. and B. Ly. - 1986. Les poissons de mer de Mauritanie. Centre National de Recherches Océanographiques et des Pêches, Nouadhibou.

Martínez, M., A. Monteagudo, A. Sandoval and P. Zas. - 2006. Islas de San Pedro. Terranova S.L., A Coruña.

Mc Cleave, J.D. and M.J. Miller. - 1994. Spawning of Conger oceanicus and Conger triporiceps (Congridae) in the Sargasso Sea and subsequent distribution of leptocephali. Environ. Biol. Fish., 39: 339-355.

Ministerio de Fomento. - 1998-2010. Puertos del Estado. Accessed 1 Jan of 2011, URL http://www.puertos.es.

Murphy, H.M. and G.P. Jenkins. - 2010. Observational methods used in marine spatial monitoring of fishes and associated habitats: a review. Mar. Freshwater Res., 61: 236-252

Muus, B.J., J.G. Nielsen, P. Dahlstrøm and B.O. Nyström. - 1999. Sea fish. Scandinavian Fishing Year Book. Wiley-Blackwell, Hedehusene.

Myers, R.A. and B. Worm. - 2003. Rapid worldwide depletion of predatory fish communities. Nature, 423: 280-283.

Myers, R.A., J.K. Baum, T.D. Shepherd, S.P. Powers and C.H. Peterson. -2007 . Cascading effects of the loss of apex predatory sharks from a coastal ocean. Science, 315: 1846-1850.

Mytilineou, C., C. Politou, C. Papaconstantinou, S. Kavadas, G. D'onghia and L. Sion. - 2005. Deep-water fish fauna in the Eastern Ionian Sea. Belg. J. Zool., 135: 229-233.

Oca, J., I. Masalo and L. Reig. - 2005. Acoustic doppler velocimetry allows determining daily swimming activity of sea bass $(D i$ centrarchus labrax L.). In: World Aquaculture Society (eds.), World Aquaculture, pp. 460-461. Bali.

Økland, F., C.J. Hay, T.F. Næsje, E.B. Thorstad and N. Nickandor. -2001 . Movements and habitat utilisation of radio tagged carp (Cyprinus carpio) in a reservoir in the Fish River, Namibia. NINA·NIKU Project Report, 13: 1-28.

O'Sullivan, S., C. Moriarty, R.D. FitzGerald, J. Davenport and M.F. Mulcahy. - 2003. Age, growth and reproductive status of the European conger eel, Conger conger (L.) in Irish coastal waters. Fish. Res., 64: 55-69.

Pickett, G.D., D.F. Kelley and M.G. Pawson. - 2004. The patterns of recruitment of sea bass, Dicentrarchus labrax L. from nursery areas in England and Wales and implications for fisheries man agement. Fish. Res., 68: 329-342.

Pita, P., J. Freire and A. García-Allut. - 2008. How to assign a catch value to fishing grounds when fisheries statistics are not spatially explicit. Sci. Mar., 72: 693-699.

Quignard, J.P. and A. Pras. - 1986. Labridae. In: P.J.P. Whitehead, M.L. Bauchot, J.C. Hureau, J. Nielsen and E. Tortonese (eds.) Fishes of the North-eastern Atlantic and the Mediterranean, pp. 919-942. UNESCO, Paris.

R Development Core Team. - 2008. R: A language and environment for statistical computing. R Foundation for Statistical Computing, Vienna, Austria. ISBN 3-900051-07-0, URL http:// www.R-project.org.

Rodríguez, X.L. and Vázquez, X. - 1994. Peixes do mar de Galicia. Peixes óseos: xeneralidades, clasificación e orde perciformes. Edicións Xerais de Galicia, Vigo.

Sackett, D.K., W.A. Kenneth and T.M. Grothues. - 2007. Dynamics of summer flounder, Paralichthys dentatus, seasonal migrations based on ultrasonic telemetry. Estuar. Coast. Shelf Sci., 74: $119-130$

Seaman, D.E. and R.A. Powell. - 1996. An evaluation of the accuracy of kernel density estimators for home range analysis. Ecology, 77: 2075-2085.
Seaman, D.E., J.J. Millspaugh, B.J. Kernohan, G.C. Brundige, K.J. Raedeke and R.A. Gitzen. - 1999. Effects of sample size on kernel home range estimates. J. Wildlife Manage., 63: 739-747.

Shepherd, J.G. - 1988. Fish stock assessments and their data requirements. In: J.A. Gulland (ed.), Fish population dynamics: the implications for management, pp. 35-62. John Wiley and Sons, New York.

Smith, D.G. - 1990. Congridae. In: J.C. Quero, J.C. Hureau, C. Karrer, A. Post and L. Saldanha (eds.), Check-list of the fishes of the eastern tropical Atlantic (CLOFETA), pp. 156-167. JNICT and UNESCO, Lisbon and Paris.

Swihart, R.K and N.A. Slade - 1985. Testing for independence of observations in animal movements. Ecology, 66: 1176-1184.

Topping, D.T., C.G. Lowe and J.E. Caselle. - 2005. Home range and habitat utilization of adult California sheephead, Semicossyphus pulcher (Labridae), in a temperate no-take marine reserve. Mar. Biol., 147: 301-311.

Topping, D.T., C.G. Lowe and J.E. Caselle. - 2006. Site fidelity and seasonal movement patterns of adult California sheephead Semicossyphus pulcher (Labridae): an acoustic monitoring study. Mar. Ecol. Prog. Ser., 326: 257-267.

Webber, D., G. McKinnon and G. Claireaux. - 2001. Evaluating differential pressure in the European sea bass (Dicentrarchus labrax) as a telemetered index of swimming speed. In: Electronic tagging and tracking in marine fisheries, pp. 297-298. Proceedings of the Symposium on Tagging and Tracking Marine Fish with Electronic Devices, Kluwer Academic Pub., Hawaii.

Winter, J. - 1996. Advances in underwater biotelemetry. In: Fisheries techniques, 2nd edition, pp. 555-590. American Fisheries Society, Bethesda, Maryland.

Wood, S.N. - 2000. Modelling and Smoothing Parameter Estimation with Multiple Quadratic Penalties. J. R. Statist. Soc. B., 62: 413-428.

Wood, S.N. - 2003. Thin plate regression splines. J. R. Statist. Soc. B., 65: 95-114.

Xunta de Galicia. - 2001-2010. Estadísticas oficiales de pesca de la Xunta de Galicia. Accessed 13 Jan of 2010. URL http://www. pescadegalicia.com/default.htm.

Scient. ed.: E. Macpherson.

Received October 27, 2010. Accepted March 28, 2011.

Published online October 5, 2011.

\section{SUPPLEMENTARY MATERIAL}

The following Appendixes are available through the web page http://www.icm.csic.es/scimar/supplm/sm75n4759sm.pdf

APPENDIX 1. - Image of 1 telemetry transmitter showing the Ttags glued by epoxy resin, ready for being inserted to a fish. Transmitters for L. bergylta and D. labrax had a third anchor point (see the text in materials and methods section for further details).

APPENDIX 2. - Output of the GAMs used to assess the behaviour of the fishes in captivity, to estimate the site fidelity of the fishes and to calculate the accuracy in the positioning of the telemetry transmitters. The parametric coefficients, their standard error (SE) and associated $P$ value are indicated. The reference value used in the comparisons between levels is not included. The number of observations or the range used, the degrees of freedom (df) and the $P$ value of the smooth terms are indicated. The interaction is denoted with ' $*$ '

APPENDIX 3. - Predictions made with GAMs to calculate the detection error $(D E)$ in function of the reception strength $(\mathrm{dB})$ and gain of the receiver $(\mathrm{dB})$. The values outside the range obtained in the accuracy test of the VR 100 receiver (VEMCO Ltd.) are not included.

APPENDIX 4. - Partial effect of the time elapsed since the fish was released (until day 50) by time of day (white $=$ dawn, light grey $=$ day, dark grey $=$ dusk, black $=$ night $)$ on the probability of detection of the fishes. Points represent the predictions made with GAMs. Note the different scales on the y axes. 
Movements of three large coastal predatory fishes in the northeast Atlantic: a preliminary telemetry study

PABLO PITA and JUAN FREIRE

Supplementary material 


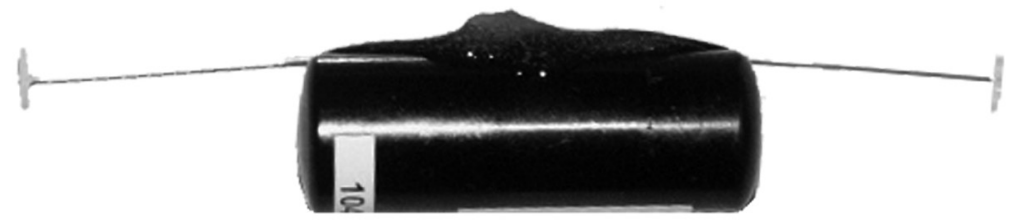

\section{$2 \mathrm{~cm}$}

APPENDIX 1. - Image of 1 telemetry transmitter showing the T-tags glued by epoxy resin, ready for being inserted to a fish. Transmitters for L. bergylta and D. labrax had a third anchor point (see the text in materials and methods section for further details).

ApPENDIX 2. - Output of the GAMs used to assess the behaviour of the fishes in captivity, to estimate the site fidelity of the fishes and to calculate the accuracy in the positioning of the telemetry transmitters. The parametric coefficients, their standard error (SE) and associated $P$ value are indicated. The reference value used in the comparisons between levels is not included. The number of observations or the range used, the degrees of freedom (df) and the $P$ value of the smooth terms are indicated. The interaction is denoted with ' $*$ '.

\begin{tabular}{|c|c|c|c|c|c|c|c|c|}
\hline \multirow[t]{2}{*}{ Model } & \multirow[t]{2}{*}{$\mathrm{N}$} & \multicolumn{3}{|c|}{ Parametric coefficients } & \multicolumn{4}{|c|}{ Smooth terms } \\
\hline & & Estimate & SE & $P$ & & Range & df & $P$ \\
\hline \multicolumn{4}{|c|}{ Feeding of L. bergylta } & 0.0037 & Time (min) & $3005-8765$ & $<0.0001$ & 1.0000 \\
\hline \multicolumn{9}{|c|}{ Activity of L. bergylta } \\
\hline Intercept & 55 & -232.3000 & 309.7000 & 0.4530 & Time $(\min )$ & $10-9125$ & 1.7230 & 0.7810 \\
\hline \multicolumn{9}{|c|}{ Activity of C. conger } \\
\hline Intercept & 146 & -3.7235 & 0.5494 & $<0.0001$ & Time $(\min ) *$ Tagged & $0-30030$ & 3.5610 & 0.0003 \\
\hline Tagged & 73 & 1.2905 & 2.1226 & 0.5430 & Time (min) * Untagged & $0-30030$ & 1.6830 & 0.0083 \\
\hline \multicolumn{9}{|c|}{ Equilibrium of C. conger } \\
\hline Intercept & 146 & 4.2070 & 0.3299 & $<0.0001$ & Time $(\min ) *$ Tagged & $0-30030$ & $<0.0001$ & 1.0000 \\
\hline Tagged & 73 & 132.8000 & 2479000.0000 & 1.0000 & Time $(\min ) *$ Untagged & $0-30030$ & 0.7353 & $<0.0001$ \\
\hline \multicolumn{9}{|c|}{ Flotation of C. conger } \\
\hline Intercept & 146 & -2.6101 & 0.3108 & $<0.0001$ & Time $(\min ) *$ Tagged & $0-30030$ & 0.9386 & $<0.0001$ \\
\hline \multirow{2}{*}{\multicolumn{9}{|c|}{ Site fidelity of C. conger }} \\
\hline & & & & & & & & \\
\hline Intercept & 3612 & -184.6729 & 43.0724 & $<0.0001$ & Time (days) $* C$. conger $\# 1$ & $0-300$ & 1.7640 & 0.0059 \\
\hline C. conger \# 2 & 1204 & -44.7657 & 56.0872 & 0.4248 & Time (days) $* C$. conger $\# 2$ & $0-300$ & 1.7220 & $<0.0001$ \\
\hline C. conger \# 3 & 1204 & 39.0230 & 50.1882 & 0.4368 & Time (days) $*$ C. conger $\# 3$ & $0-300$ & 1.6380 & $<0.0001$ \\
\hline Day & 903 & -0.8531 & 0.1253 & $<0.0001$ & & & & \\
\hline Dusk & 903 & -1.6350 & 0.1570 & $<0.0001$ & & & & \\
\hline Nigth & 903 & 0.2988 & 0.1016 & 0.0033 & & & & \\
\hline \multicolumn{9}{|c|}{ Site fidelity of D. labrax } \\
\hline Intercept & 3613 & -97.9246 & 6.8590 & $<0.0001$ & Time (days) * D. labrax \# 1 & $0-300$ & 1.8080 & $<0.0001$ \\
\hline D. labrax \# 5 & 1204 & 89.2603 & 6.8615 & $<0.0001$ & Time (days) * D. labrax \# 2 & $0-300$ & 1.1850 & $<0.0001$ \\
\hline D. labrax \# 6 & 1204 & -9456.6866 & 720.8635 & $<0.0001$ & Time (days) $* D$. labrax \# 3 & $0-300$ & 1.6760 & $<0.0001$ \\
\hline Day & 903 & 0.4833 & 0.1100 & $<0.0001$ & & & & \\
\hline Dusk & 903 & -1.4726 & 0.1147 & $<0.0001$ & & & & \\
\hline Nigth & 904 & 0.4833 & 0.1108 & $<0.0001$ & & & & \\
\hline \multicolumn{9}{|c|}{ Accurancy of tags (m) } \\
\hline Intercept & 2550 & 3.8770 & 0.0228 & $<0.0001$ & Signal $(\mathrm{dB}) *$ Gain $0 \mathrm{~dB}$ & $61-97$ & 7.3100 & $<0.0001$ \\
\hline Gain $6 d B$ & 475 & -0.0431 & 0.0314 & 0.1690 & Signal $(\mathrm{dB}) *$ Gain $6 \mathrm{~dB}$ & $59-100$ & 8.1060 & $<0.0001$ \\
\hline Gain $12 d B$ & 448 & 0.0194 & 0.0348 & 0.5770 & Signal $(\mathrm{dB}) *$ Gain $12 \mathrm{~dB}$ & $69-99$ & 7.715 & $<0.0001$ \\
\hline Gain $18 d B$ & 430 & 0.0014 & 0.0326 & 0.9660 & Signal $(\mathrm{dB}) *$ Gain $18 \mathrm{~dB}$ & $70-97$ & 4.329 & $<0.0001$ \\
\hline Gain $24 d B$ & 426 & -7.2520 & 1.7530 & $<0.0001$ & Signal $(\mathrm{dB}) *$ Gain $24 \mathrm{~dB}$ & $70-91$ & 7.981 & $<0.0001$ \\
\hline Gain $30 \mathrm{~dB}$ & 371 & -380.2000 & 236.2000 & 0.1080 & Signal $(\mathrm{dB}) *$ Gain $30 \mathrm{~dB}$ & $70-91$ & 7.909 & $<0.0001$ \\
\hline
\end{tabular}


APPENDIX 3. - Predictions made with GAMs to calculate the detection error $(D E)$ in function of the reception strength $(\mathrm{dB})$ and gain of the receiver $(\mathrm{dB})$. The values outside the range obtained in the accuracy test of the VR 100 receiver (VEMCO Ltd.) are not included.

\begin{tabular}{|c|c|c|c|c|c|c|c|c|c|c|c|c|c|c|c|c|c|c|}
\hline \multicolumn{4}{|c|}{$\begin{array}{lc}\text { Strength } & \text { Gain }(\mathrm{dB}) \\
(\mathrm{dB}) & 0\end{array}$} & & \multicolumn{3}{|c|}{12} & \multicolumn{3}{|c|}{18} & \multicolumn{3}{|c|}{24} & \multicolumn{3}{|c|}{30} \\
\hline 100 & - & & - & 2.61 & 1.48 & 4.09 & - & - & - & - & - & - & - & - & - & - & - & \\
\hline 95 & 19.98 & 1.07 & 21.05 & 17.26 & 1.07 & 18.33 & 16.90 & 1.07 & 17.98 & 17.44 & 1.06 & 18.50 & - & - & - & - & - & \\
\hline 90 & 41.10 & 1.05 & 42.16 & 45.13 & 1.05 & 46.18 & 44.26 & 1.06 & 45.32 & 40.99 & 1.05 & 42.05 & 42.44 & 1.07 & 43.52 & - & - & \\
\hline 85 & 61.83 & 1.04 & 62.87 & 61.45 & 1.04 & 62.49 & 67.53 & 1.05 & 68.57 & 68.85 & 1.04 & 69.89 & 61.48 & 1.06 & 62.53 & 26.52 & 1.04 & 27.55 \\
\hline 80 & 85.99 & 1.04 & 87.03 & 81.13 & 1.04 & 82.17 & 85.29 & 1.04 & 86.32 & 86.17 & 1.03 & 87.20 & 84.82 & 1.04 & 85.86 & 84.53 & 1.06 & 85.59 \\
\hline 75 & 94.94 & 1.07 & 96.01 & 93.03 & 1.05 & 94.08 & 92.08 & 1.06 & 93.14 & 97.42 & 1.06 & 98.48 & 83.32 & 1.10 & 84.42 & 90.71 & 1.24 & 91.95 \\
\hline 70 & 100.89 & 1.07 & 101.96 & 98.06 & 1.08 & 99.15 & 92.04 & 1.18 & 93.21 & 100.66 & 1.21 & 101.87 & 85.69 & 1.35 & 87.04 & 60.09 & 1.45 & 61.54 \\
\hline 65 & 99.83 & 1.10 & 100.93 & 101.11 & 1.15 & 102.27 & - & - & - & - & - & - & - & - & - & - & - & \\
\hline 60 & & & - & 100.29 & 1.17 & 101.47 & - & - & - & - & - & - & - & - & - & - & - & \\
\hline
\end{tabular}
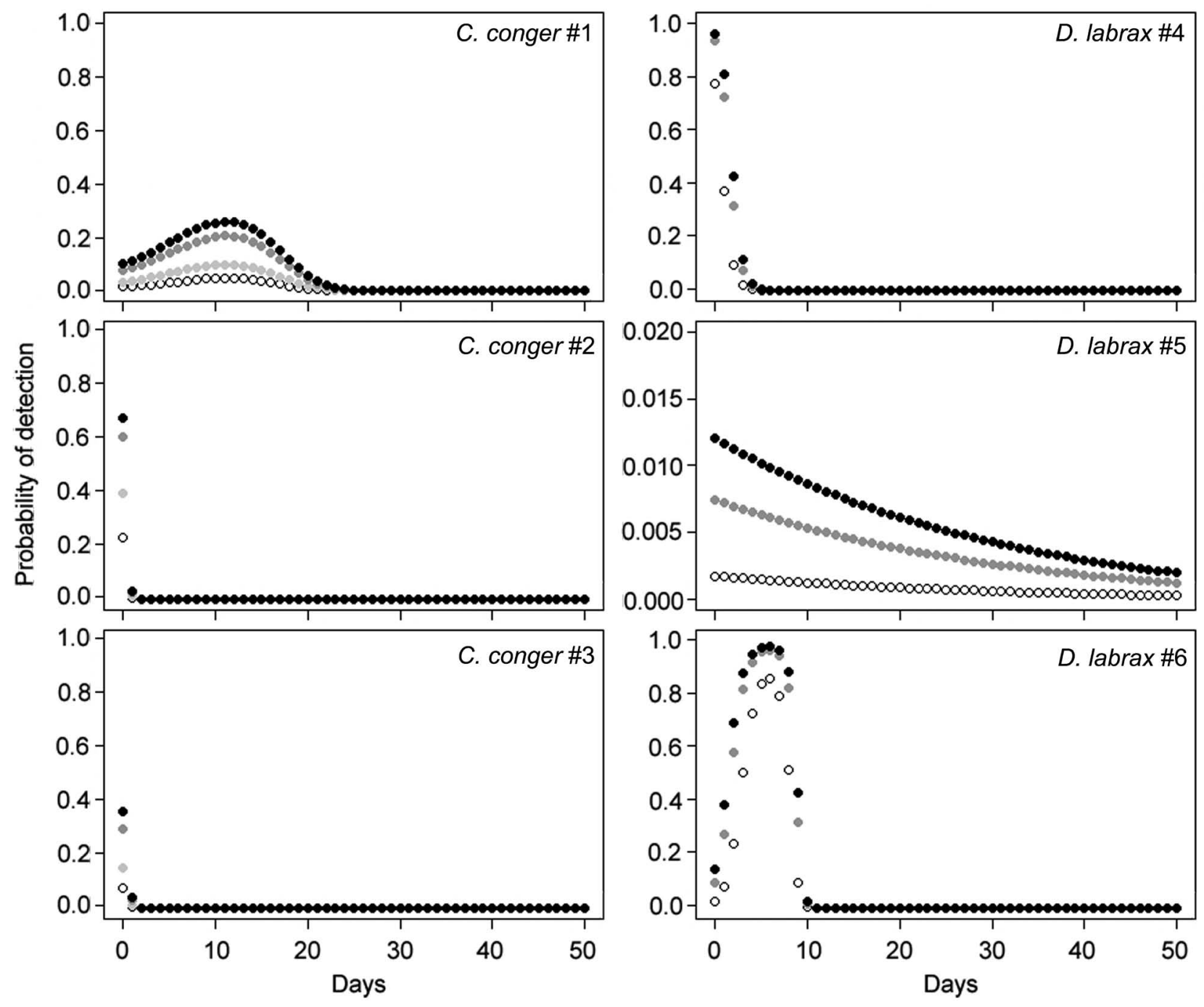

APPENDIX 4. - Partial effect of the time elapsed since the fish was released (until day 50) by time of day (white $=$ dawn, light grey $=$ day, dark grey $=$ dusk, black $=$ night $)$ on the probability of detection of the fishes. Points represent the predictions made with GAMs. Note the different scales on the y axes. 